\title{
Does the reticulin binding property of cereal proteins demonstrable in vitro have pathogenetic significance for coeliac disease?
}

\author{
D J UNSWORTH AND E J HOLBOROW
}

From the MRC Immunology Group, Bone and Joint Research Unit, The London Hospital Medical College,
London

SUMMARY We used an indirect immunofluorescence technique, using rabbit antisera against cereal protein extracts, to determine which cereal proteins bind to reticulin in tissue sections and which do not. Wheat albumin extracts and globulins and gliadin extracts from a range of different wheat varieties, and prolamine extracts of barley and rye each bound to reticulin in vitro, while prolamine extracts of maize and rice did not. Wheat gluten subfractions were also tested. Subfractions $B$ and $C$ and subfractions $B_{2}$ and $B_{3}$ did bind, but fraction $A$ and subfraction $B_{1}$ did not. The results suggest an association between in vitro reticulin binding and the ability to induce gluten sensitive enteropathy on feeding.

Three observations seem to implicate reticulin in the pathogenesis of gluten sensitive enteropathy. Firstly, the fact that wheat gliadins bind selectively to reticulin in cryostat sections of rat and human tissues ${ }^{1}$ secondly, that following gluten challenge of coeliac patients the earliest observable histological change is in the subepithelial connective tissue, ${ }^{2}$ and thirdly, the known association of the R1-type anti-reticulin antibody (R1-ARA) with gluten sensitive enteropathy. ${ }^{3-6}$

For this reason we decided to test various biochemically defined wheat protein preparations, extracts of other cereals, and non-cereal food proteins for their ability to bind to reticulin in cryostat tissue sections. Comparison of our results with those of previously reported studies designed to assess which cereal proteins induce gluten sensitive enteropathy suggests an association between in vitro reticulin binding capacity and in vivo toxicity.

\section{Methods}

The reticulin binding studies were carried out on $6 \mu$ thick unfixed cryostat sections of human small intestine from normal subjects and coeliac patients, and of normal rat liver, kidney and stomach. Tissue bound cereal/food protein was detected by indirect

Address for correspondence: Dr D J Unsworth, Child Health, St Bartholomew's Hospital, London EC1.

Received for publication 3 December 1984 immunofluorescence with rabbit antisera raised against the proteins in question, and FITCconjugated sheep antiserum to rabbit Ig (Wellcome Reagents) in the final step. An R1-like reticulin immunofluorescence staining pattern indicated reticulin binding.

The cereal protein preparations used were either prepared in this laboratory or were the generous gifts of cereal protein chemists. Dr M R Booth (Rank Hovis McDougall Research Laboratories, High Wycombe) kindly provided milled flours from hexaploid (Flander's, Maris-Huntsman, Crossbow), tetraploid (Emmer) and diploid (Einvorn) bread wheats, and from common varieties of barley, rye, maize, and rice. Bread wheats are normally hexaploid. The tetraploid and diploid varieties lack genomes coding for groups of gliadins. Crude prolamines (gliadin) were prepared by extraction of defatted flour with $70 \%$ ethanol/water $(\mathrm{v} / \mathrm{v})$ for two hours with stirring $(3.2 \mathrm{ml}$ solvent $/ \mathrm{g}$ flour $)$, as described by Ewart. ${ }^{7}$ The product was dialysed overnight against water and freeze dried. Wheat albumins and globulins were obtained from defatted Flander's and Maris-Huntsman flours by direct extraction with $1 / 5 \%$ saline, and gluten extracts were obtained from the same flours (after extraction of wheat albumins and globulins and gliadins) by extraction with $0 \cdot 1 \mathrm{M}$ acetic acid. These extracts were characterised by PAGE in albumin lactate buffer $\mathrm{pH} 3 \cdot 1 .{ }^{8}$ Frazer's fraction III (FIII) was 
derived from Flander's and Maris-Huntsman glutens as described by Frazer et al. ${ }^{9}$ Subfractions A, B, C and $B_{1}, B_{2}$ and $B_{3}$ derived from Frazer's fraction III of $\mathrm{BDH}$ gluten were prepared by ultrafiltration ${ }^{10}$ and gel filtration, ${ }^{11}$ and were kindly provided by Professor R E Offord. Preparations of purified 'A' gliadins derived from Scout 66 by the method of Bernardin et $a l^{12}$ were kindly provided by $\operatorname{Dr} \mathrm{D}$ Kasarda. The non-cereal food proteins (ovalbumin, bovine serum albumin, B-lactoglobulin and casein) were purchased from Sigma Ltd.

New Zealand white rabbits were used to raise antisera against extracts of wheat albumins and globulins, gliadins, and glutenins derived from Flander's and Maris-Huntsman flours, against prolamine extracts of barley, rye, and maize, and Kasarda's ' $A$ ' gliadins, and against each of the non-cereal food proteins mentioned above. In each case protein at a concentration of $2 \mathrm{mg} / \mathrm{ml}$ of water or phosphate buffered saline $\mathrm{pH} 7.2$ was emulsified with an equal volume (usually $0.5 \mathrm{ml}$ ) of Freund's complete adjuvant, and injected intramuscularly over several sites. Several antisera (at least three) were raised against each cereal extract. For each immunogen the resulting antisera showed the same spectrum of reactivities. After one month, the animals were boosted (1 $\mathrm{mg}$ in phosphate buffered saline) intraperitoneally, and bled two weeks later. The antisera raised against cereal protein extracts were shown to have high titres of reactivity against the immunising antigen by the ELISA method, as described previously. ${ }^{13}$ Prolamine extracts were coated on the ELISA plates in $60 \%$ ethanol/water $(\mathrm{v} / \mathrm{v})$. Wheat albumin and globulins were coated in phosphate buffered saline and glutenins were coated in $0.1 \mathrm{M}$ acetic acid. The antisera raised against the non-cereal food antigens were shown to give strong precipitation reactions on double immunodiffusion in gel ( $1 \%$ agarose IBF in barbitone buffered saline $\mathrm{pH} \mathrm{8.3)} \mathrm{and} \mathrm{to} \mathrm{have} \mathrm{high} \mathrm{specific} \mathrm{antibody} \mathrm{titres} \mathrm{of}$ ELISA. A high titre antiserum raised against Capelle-Desprez (hexaploid wheat) gliadins was the generous gift of Dr J Ewart (Flour Milling Research Unit, Chorleywood, UK). When tested for tissue reactivity by indirect immunofluorescence on unpretreated cryostat tissue sections, none of the above antisera showed antireticulin reactivity.

The reticulin binding experiments used each of the test proteins at a concentration of $1.0 \mathrm{mg} / \mathrm{ml}$, and 10 fold dilutions thereof, in either distilled water, or phosphate buffered saline, or both. Various other solvents were tried - for example, $60 \%$ ethanol/water $(\mathrm{v} / \mathrm{v})$, or $0 \cdot 1 \mathrm{M}$ acetic acid, and $1 \%$ sodium dodecyl sulphate, but it was found that the majority of these solvents adversely affected the tissue so that gliadin when dissolved in these, failed to bind. Problems were encountered, therefore, especially with glutenin extracts, such that solvents of choice with regard to achieving good solubility unfortunately impaired tissue binding. In most cases, however, cereal extracts could be dissolved in water or phosphate buffered saline, and gliadin dissolved in both these did show binding. Hence the above mentioned solvents were not used.

Cryostat sections were covered with the different protein solutions and binding allowed to take place for two hours at room temperature. After unbound protein had been washed off in a stirred phosphate buffered saline bath, bound material was detected using the appropriate rabbit antiserum in an indirect immunofluorescence technique. Extensive cross reactivity between prolamine (gliadin) extracts of different wheats allowed the use of antisera raised against Flander's gliadins and/or Maris-Huntsman gliadins to detect binding of any of the gliadin extracts. Tissue bound FIII and its subfractions could be detected with antisera raised against defatted wheat flour. In control experiments, normal rabbit sera were used in place of the specific antisera.

\section{Results}

The results were the same irrespective of whether rat or human tissues were used and no differences were observed between results with coeliac small intestine (Fig. 1a) and normal human gut tissue. As shown in Table 1, with the exception of maize and rice extracts each of the prolamine extracts bound to reticulin in vitro. Maize and rice were the cereals which gave the lowest prolamine yields (see Table 1). As Table 2 shows, both saline (albumin and globulin) and ethanol (gliadin) extracts of Flander's and Maris-Huntsman wheats bound to reticulin. Titration studies showed that gliadin binding could be demonstrated down to a dilution of $10^{-5} \mathrm{mg} / \mathrm{ml}$, whilst the end point dilution for binding of albumins and globulins was only $10^{-2} \mathrm{mg} / \mathrm{ml}$. Attempts to ascertain whether glutenins also bound were frustrated by the difficulty in obtaining glutenins in soluble form for testing. Pretreatment of tissues with $0 \cdot 1 \mathrm{M}$ acetic acid and certain other solvents (each of which allowed solubilisation of glutenins) was found to adversely affect gliadin binding, so that failure to show reticulin binding with glutenins dissolved in these solvents, may have been attributable to the effect of the solvent. Table 3 shows the results of binding experiments with FIII and its subfractions. Frazer's fraction III of Flander's BDH gluten both showed reticulin binding. Subfractions B, C and $B_{2}$ and $B_{3}$ showed reticulin binding, whilst subfractions $A$ and $B_{1}$ did not. ' $A$ ' gliadins also bound to 

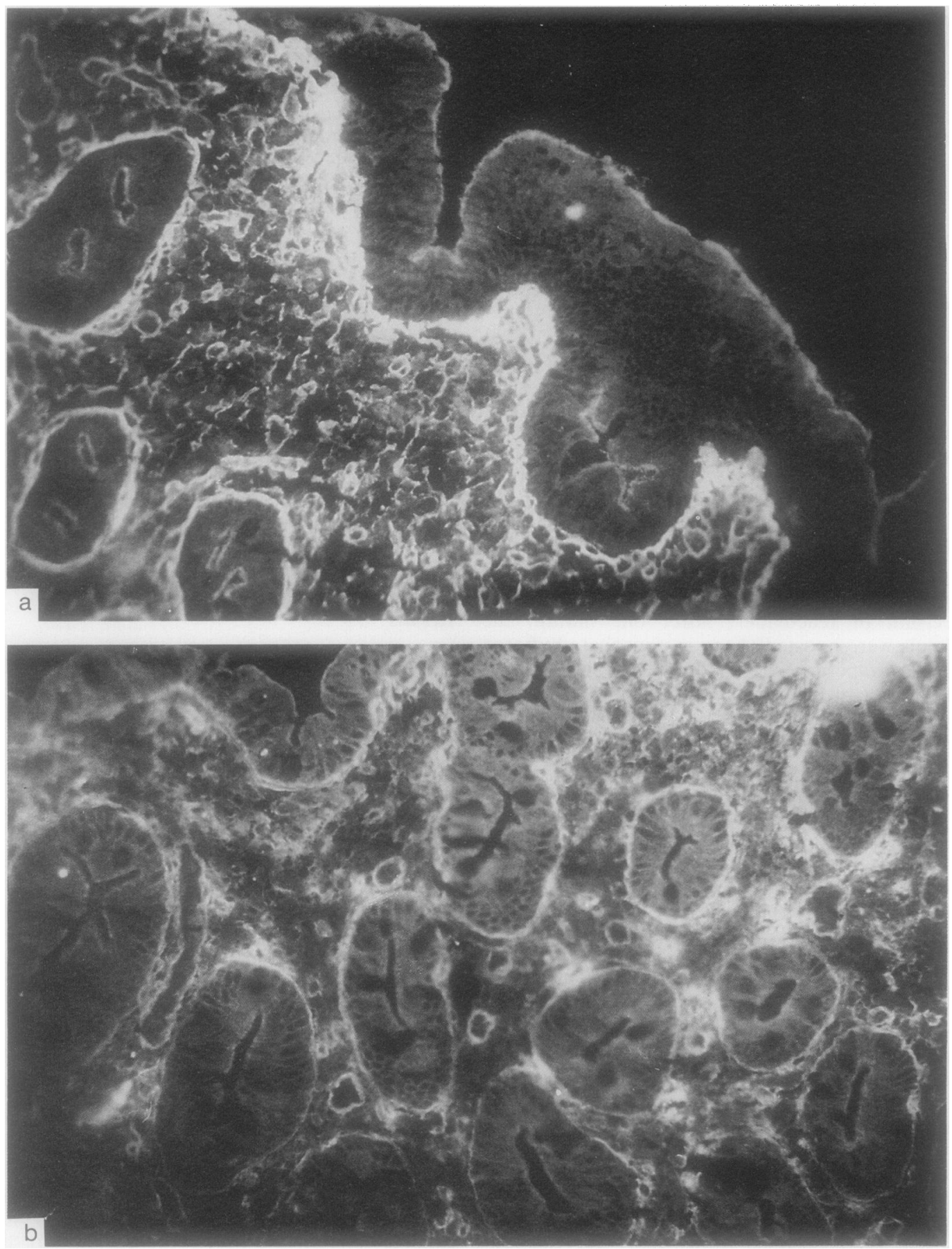

Fig. 1 (a) Indirect immunofluorescence staining of reticulin fibres (using specific rabbit antiserum) in a section of small intestine obtained from a child with untreated coeliac disease. (b) Binding of gliadin (shown by indirect immunofluorescence using rabbit antigliadin antibody) to reticulin in tissue sections cut from the same biopsy specimen as in $1 a$. 
Table 1 In vitro reticulin binding experiments with prolamine extracts of wheat and other cereals

\begin{tabular}{lccc}
\hline Prolamine type & $\begin{array}{l}\text { Prolamine yield } \\
\text { (\% starting protein) }\end{array}$ & $\begin{array}{l}\text { In vitro } \\
\text { Reticulin binding }\end{array}$ & $\begin{array}{l}\text { Reported } \\
\text { toxicity }\end{array}$ \\
\hline Hexaploid wheats & $18-22$ & + & Yes ${ }^{17}$ \\
Tetraploid wheats & 14 & + & Not done \\
Diploid wheats & 9 & + & Not done \\
Barley & 16 & + & Yes $17-19$ \\
Rye & 14 & + & Yes \\
Maize & $0 \cdot 4-19$ & No \\
Rice & $0 \cdot 04$ & - & No ${ }^{19} 20$ \\
\hline
\end{tabular}

reticulin. Of the non-cereal food proteins, only casein showed any degree of reticulin binding, but this was very weak and demonstrable only with casein as a concentration of $1 \mathrm{mg} / \mathrm{ml}$ or higher.

The $\mathrm{R} 1$ reticulin staining patterns given by each of the cereal proteins which bound were essentially indistinguishable from one another with one exception. The wheat albumin and globulin extracts differed in giving reticulin binding patterns on rat liver (Fig. 2a) which were distinguishable from that seen with gliadin (and other) extracts (Fig 2b), the latter giving more extensive staining of sinusoidal connective tissue in sections of liver.

\section{Discussion}

These results show that the ability to bind to reticulin is not peculiar to gliadins. With the exception of casein, the non-cereal food proteins tested did not bind. Casein is possibly the agent responsible for cow's milk sensitive enteropathy in children. As the results in Table 1 show, the reticulin binding property of cereal proteins seems to be associated with prolamines because maize and rice, which are low in prolamine content, did not show it. As Table 2 shows, however, wheat albumins and globulins, as well as gliadins, show reticulin binding. This was surprising, because the

Table 2 Reticulin binding of wheat proteins

\begin{tabular}{|c|c|c|}
\hline & $\begin{array}{l}\text { Reticulin } \\
\text { binding }\end{array}$ & $\begin{array}{l}\text { Titration } \\
\text { end point }\end{array}$ \\
\hline $\begin{array}{l}\text { Flanders } \\
\text { Albumins and globulins } \\
\text { Gliandins } \\
\text { Glutenins }\end{array}$ & $\begin{array}{l}+ \\
+ \\
\text { Not done }\end{array}$ & $\begin{array}{l}10^{-2} \mathrm{mg} / \mathrm{ml} \\
10^{-5} \mathrm{mg} / \mathrm{ml} \\
\text { Not done }\end{array}$ \\
\hline $\begin{array}{l}\text { Maris-Huntsman } \\
\text { Albumins and globulins } \\
\text { Gliadins } \\
\text { Glutenins }\end{array}$ & $\begin{array}{l}+ \\
+ \\
\text { Not done }\end{array}$ & $\begin{array}{l}10^{-3} \mathrm{mg} / \mathrm{ml} \\
10^{-6} \mathrm{mg} / \mathrm{ml} \\
\text { Not done }\end{array}$ \\
\hline
\end{tabular}

two groups of proteins are very different biochemically ${ }^{14}$ and because the albumins and globulins are thought to be harmless. Although the saline extracts were apparently gliadin free on electrophoresis, minor gliadin contamination may have been present in the albumin and globulin extracts to account for the reticulin binding they appeared to give. This possibility is supported by the lower end point dilution obtained with gliadin extract in reticulin binding experiments, as compared with albumin and globulin extracts. On the other hand, the slightly different $\mathrm{R} 1$ reticulin binding patterns seen with the two types of extract suggests that they may contain reticulin binding proteins with different properties.

The reported clinical toxocity of each of the cereal protein preparations used is shown in Tables 1 and 3. Wheat albumins and globulins (which bind to reticulin but are thought to be non-toxic) are exceptions to the rule that cereal proteins/fractions known to be toxic bind to reticulin in vitro, whilst those found to be non-toxic do not. It should be noted, however, that interpretation of feeding studies designed to assess toxicity depends upon induction of histological relapse, and the failure of a given preparation to induce relapse on feeding may be because of the use of too low a 'dose' or too brief exposure. This possibility is supported by the finding that enteropathy can be induced in predis-

Table 3 In vitro reticulin binding of Fracer's Fraction III and subfractions thereof

\begin{tabular}{lll}
\hline & $\begin{array}{l}\text { Reticulin } \\
\text { binding }\end{array}$ & $\begin{array}{l}\text { Reported } \\
\text { toxicity }\end{array}$ \\
\hline BDH gluten FIII & + & Yes $^{9}$ \\
Subfraction A & - & No $^{10}$ \\
Subfraction B & + & Yes $^{10}$ \\
Subfraction C & + & Yes $^{10}$ \\
Subfraction B & - & No \\
Subfraction B $_{2}$ & + & Yes $^{11}$ \\
Subfraction B & Yes & \\
Flander's FIII & + & Yes $^{9}$ \\
'A' gliadin & + & Yes $^{20}$ \\
\hline
\end{tabular}



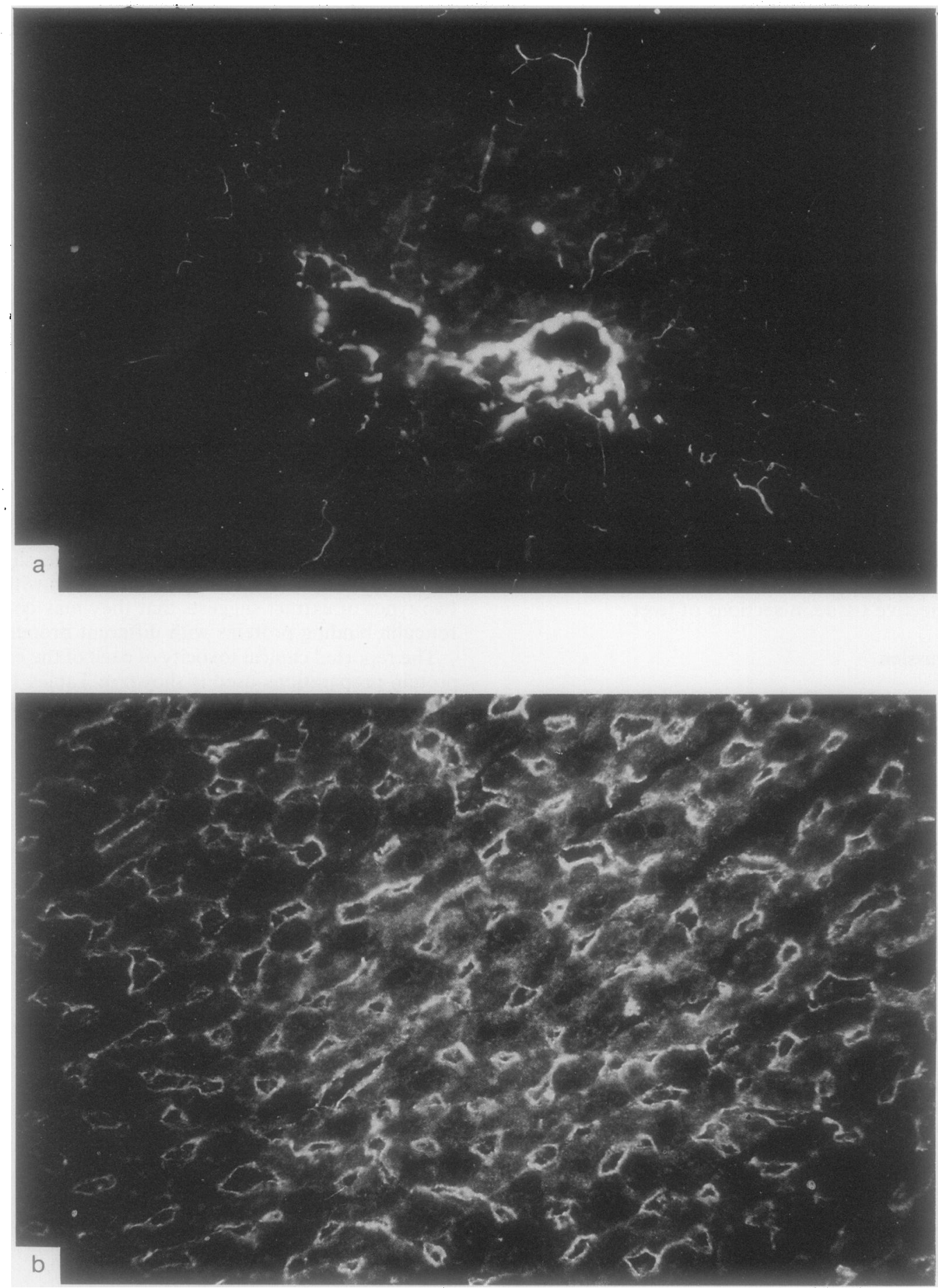

Fig. 2 (a) Binding of wheat albumins and globulins on a cryostat section of rat liver. (b) Binding of $\alpha$-gliadins to a cryostat section of rat liver. 
posed individuals - for example, coeliac relatives, by increasing the level of gluten intake. ${ }^{16}$

Thus, the belief that wheat albumins and globulins are innocuous should perhaps be reconsidered in the light of the possible association between the ability of cereal proteins to bind to reticulin in vitro and their ability to induce gluten sensitive enteropathy on feeding.

These studies would not have been possible without the generous help of Professor Offord and his team who kindly provided subfractions of wheat gluten, Drs M Booth and P Ellis of Rank Hovis McDougall, who provided wheat flours for prolamine extraction and electrophorectic analysis of the resulting extracts, and Professor D Kasandra for a gift of 'A' gliadin.

\section{References}

1 Unsworth DJ, Johnson GD, Haffeden G, Fry L, Holborow EJ. Binding of wheat gliadin in vitro to reticulin in normal and dermatitis herpetiformis skin. J Invest Dermatol 1981; 76: 88-93.

2 Shiner M. Ultrastructural changes suggestive of immune reactions in the jejunal mucosa of coeliac children following gluten challenge. Lancet 1973; 1: 1202.

3 Seah PP, Fry L, Holborow EJ, Rossiter MA, et al. Anti-reticulin antibody: Incidence and diagnostic significance. Gut 1983; 14: 311-5.

4 Alp MH, Wright R. Autoantibodies to reticulin in patients with idiopathic steatorrhaea, coeliac disease, and Crohn's disease, and their relation to immunoglobulins and dietary antibodies. Lancet 1971; 2: 682 .

5 Brown IL, Ferguson A, Carswell F, Horne CHW, McSween RNM. Autoantibodies in children with coeliac disease. Clin Exp Immunol 1973; 13: 377.

6 Unsworth DJ, Walker SMith JA, Holborow EJ. Gliadin and reticulin antibodies in childhood coeliac disease. [Letter] Lancet 1983; 1: 874-5.

7 Ewart JAD. Isolation of a Capelle-Desprez gliadin. J Sci Ed Agric 1975; 26: 1021-5.
8 Bushuk W, Zillman RA. Wheat cultivar identification by gliadin electrophoretograms. Can J Plant Sci 1977; 58: 505 .

9 Frazer AC, Fletcher RI, Ross CAC, Shaw B, Sammons HG, Schneider R. Gluten induced enteropathy - The effect of partially digested gluten. Lancet 1959; 2: 252.

10 Dissanyake AS, Jerone DW, Offord RE, Truelove SC, Whitehead $\mathrm{R}$. Identifying toxic fractions of wheat gluten and their effect on the jejunal mucosa in coeliac disease. Gut 1974; 15: 931.

11 Offord RE, Anand BS, Piris J, Truelove SC. Further subfractionation of digests of gluten. In: McNicholl B, McCarthy CF, Fottrell PF eds. Perspectives in coeliac disease: proceedings of the 3rd International Coeliac Symposium Lancaster, MTP Press, 1978: 25-9.

12 Bernardin JE, Kasarda DD, Mecham DK. Preparation and characterization of $\alpha$-gliadin. J Biol Chem 1967; 242: 445 .

13 Unsworth DJ, Leonard JN, McMinn RMH, Swain AF, Holborow EJ, Fry L. Anti-gliadin antibodies and small intestinal mucosal damage in dermatitis herpetiformis. Br J Dermatol 1981; 105: 653.

14 Kasarda DD, Bernardin JE, Nimmo CC. Wheat proteins. In: Pomeranz $\mathrm{Y}$, ed. Advances in cereal science and technology. Vol 1. St Paul, Minnesota: American Association of Cereal Chemists, 1976.

15 Auricchio S, De Viria B, Carta De Angetis L, Silano V. Alpha-amylase protein inhibitors from wheat in coeliac disease. Lancet 1974; 1 : 98.

16 Doherty M, Barry RG. Gluten induced mucosal changes in subjects without overt small bowel disease. Lancet 1981; 1: 517.

17 Van de Kamer JH, Weijers HA, Dicke WK. Coeliac Disease IV. An investigation into the injurous constituents of wheat in connection with their actions on patients with coeliac disease. Acta Paediatr 1953; 42: 223.

18 Dicke WK, Weijers HA, Van de Kamer JH. The presence in wheat of factor having deleterious effect in cases of coeliac disease. Acta Paediatr (Uppsala) 1953; 42: 34.

19 Rubin CE, Brandberg LL, Flick AL, et al. Biopsy studies on the pathogenesis of coeliac sprue. In: Wolstenholm, GEW, Cameron MP eds. International biopsy. CIBA Foundation Study No 14. London: CIBA Fdn, 1962: 67-83.

20 Anand BS, Piris J, Truelove SC. The role of various cereals in coeliac disease. $Q J$ Med 1978; 185: 101. 